\title{
Geç Antik Çăg Amphoralarında Görülen Yazıt ve Mühürler Işığında Annona Sistemi: LRA 1, LRA 2, LRA 3 ve Zeest 80
}

\author{
[THE ANNONA SYSTEM FROM THE POINT OF AMPHORAS, INSCRIPTIONS, \\ AND STAMPS OF LATE ANTIQUE: LRA 1, LRA 2, LRA 3 AND ZEEST 80]
}

\author{
Ülkü KARA
}

\begin{abstract}
Anahtar Kelimeler
Geç Antik Dönem, Amphora, Mühür, Dipinto, Graffito, Annona civicia ve Annona Militaris.
\end{abstract}

\begin{abstract}
Keywords
Late Antique Period, Amphora, Stamp, Dipinto, Graffito, Annona Civicia and Annona Militaris.
\end{abstract}

\section{ÖZET}

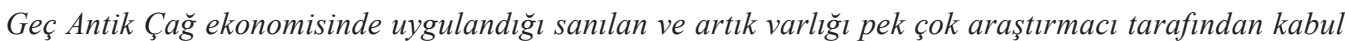
edilen, vergi toplama ve ayni dağıtma sistemi olan annonanın (annona civicia ve annona militaris) eylemlerinden biri “ürünün yer değiştirmesi/nakliyesi” dir. Vergi karşılığında toplanan ürünlerin denizaşırı ve uzak coğrafyalara aktarılması gibi önemli bir organizasyonda kullanılan amphoralar, kabın temin edilmesinden ürünün bozulmadan varışına kadar geçen süreçte oldukça önemlidir. Ayrıca, amphoranın formu kadar üzerindeki yazıtlar ve mühürler de kabı temsil eden öğelerdendir. Sözü edilen mühür ve yazı biçimleri (graffito ve dipinto) dönemin ekonomik, din ve dil özelliklerini yansıtmasının yanı sıra, annnona sisteminin uygulamalarl olarak da kabul edilmektedir. Sunulan çalışmada; Doğu Roma İmparatorluğu'nun son dönemindeki (MS 4. - 7. yüzyıllar) boyunca annona organizasyonuna yönelik üretildiği sanılan ya da bunun için kullanıldı ̆̆ düşünülen ve Akdeniz çevresinde yoğun olarak yayılım gösteren dört amphora tipi (LRA 1, LRA 2, LRA 3 ve Zeest 80); formlarl, üretimleri ve üzerinde görülen yazıt ve mühürler özelinde ele alınmış ve annona sistemi içinde yer alıp almadıkları irdelenmiştir.

\section{ABSTRACT}

Transport/Displacement of products is an essential element of the tax in-kind (annona civicia and annona militaris) and distribution practice which is deemed to be conducted in the economy during the Eastern Roman Empire Period, as approved by a majority of researchers today. Amphoras used in the transport process of products collected as tax to the overseas or distant locations stand as essential in the period between the provision/production of the vessels and the date of arrival to the location in proper condition. Inscriptions and stamps on the amphoras represent it along with the form. It may be suggested that the abovementioned inscriptions and stamps reflecting the economic, religious, and language properties of the period, may also have some features serving the annona system. This paper examines the four amphorae types (LRA 1, LRA 2, LRA 3, and Zeest 80) common in the Mediterranean Region which are deemed to be produced/used for purposes of annona organization in the Late Roman - Early Byzantine periods (4th - 7th c. AD) with a specific focus on the inscriptions and stamps and inspects their position, if any, in

\section{Giriș}

the annona system.

Akdeniz'in genelinde bir dünya ekonomisine doğru evrilmiş olan Geç Roma - Erken Bizans Dönemi ekonomisini, bölümlere ayrılmış ekonomik alanların bir bileşimi şeklinde tanımlamak mümkündür. ${ }^{1}$ Günümüzde pek çok araştırmacının kabul ettiği üzere; bu dönemin

1 Carrié 2012: 26. ekonomik sistemi, ne tamamen ticarete ne de tamamen takas ürünlerine dayalıyd1.2 ${ }^{2}$ Bununla birlikte, Geç Roma Dönemi ekonomisinin tarih öncesi dönemlerdeki ilkel takas sistemine evrildiği düşüncesi, modern tarihçiler tarafından dönemin vergi sisteminde yanlış anlaşılmalara

2 Jones 1964: 824-872; Garnsey ve Whittaker 1998: 213, 315; Laiou 2002: 679-696; Paterson 2010: 142143; Carrié 2012: 13vd; Mitchell 2016: 549-552. 
yol açmasının sonucu, olarak yorumlanmaktadır. ${ }^{3}$ Diğer taraftan, uzak mesafe ticaretinin genel hacmi içinde, gida tedariğini sağlayan annonanın öneminin abartıldığ 1 düşüncesi de dikkat çekicidir. ${ }^{4} \mathrm{Bu}$ dönemde, merkezde ticaret veya takasın olduğu kabul edilse dahi, yağma ve hediye gibi dolaşım mekanizmalarının da olduğu ve Doğu Roma İmparatorluğu'nun, dönemin ticari faaliyetlerinde devlet olarak büyük bir rol üstlendiği de düşünülmektedir. ${ }^{5}$ Ancak, sistemin detaylarına dair henüz aydınlatılmamış konuların başında; önerilen bu sözde modelin çizilmemiş sınırları ve ticaretin hacmi gelmektedir. Öte yandan, modelin sistematiği, varsa standartları veya değişkenlikleri gibi başlıklar, arkeolojik ya da tarihsel verilerin açıklamada eksik kaldığ 1 noktalardan bazılarıdır. Ek olarak, özellikle takas uygulamasında "paraya çevirme" veya "karşılık/ hediye değişimi" benzeri tanımların içinin doldurulabilmesi de henüz araştırma ve spekülasyona açık konulardandır. ${ }^{6}$ Tüm bu veri ve kanıt eksikliğine rağmen, takas sisteminin işleyişinde Akdeniz'in doğusu ve batısı arasında hem bölgesel hem de dönemsel (Roma İmparatorluk ve Geç Roma İmparatorluk Dönemi) açıdan farklılıklar olduğu anlaşılmaktadır. ${ }^{7}$

Geç Roma İmparatorluğu'nda askeri harcama ve askerlerin maaşı için yüksek bütçelere ihtiyaç duyulmuştur. ${ }^{8}$ Ordunun ve devletin sürdürülebilirliğinin ise, büyük oranda vergi, haraç ve imparatorluk topraklarının kiraya verilmesine dayandığını söylemek mümkündür. Arazi sahipleri ya da araziyi kullananlar tarafından ödenen tarımsal vergilerin oranının yüksek olmasına karşın, kentlinin vergi yükü daha azdır. Bununla birlikte, tüm vergilendirmenin nakit olarak yapılmadığı, ayni ve zorunlu hizmet olarak yapılabilmesinin yanı sıra, nakit dışındaki vergi-

3 Ward-Perkins 2001: 174; Carrié 2012: 23.

4 Carrié 2012: 20.

5 M. Mango 2009: 3.

6 Garnsey ve Whittaker 1998: 312vd.; Carrié 2012: 2126. Bat1 Akdeniz'deki annona sistemine dair genel bir değerlendirme için, bkz: Peacock ve Williams 1986: 54-63. Ekonomi ve vergi konusunda güncel bir analiz için, bkz: Bowman 2018: 27vd.

7 Akdeniz'in doğu ve batısına dair detaylı bir vergi ve maaliyet incelemesi için bkz: Williams ve Friell 1999: $115 \mathrm{vd}$.

8 Treadgold 2015: 364. İmparatorluk ve ordu bütçesi için, bkz: Hopkins 1980: 101-123, 124-125; Hendy 1985: 157-421; Pollard 2006: 219-225. lerin de nakde çevrilebildiği de bilinmektedir. ${ }^{9}$ Benzer konularda Akdeniz'in batısındaki uygulamalara bakıldığında ise, vergi düzenlemeleri konusunda Doğu ve Batı Roma İmparatorlukları arasında farklılıklar bulunduğu anlaşılmaktadır. ${ }^{10}$ Örneğin, Batı'da, kölelerin çalıştığı büyük arazilerin sahiplerinden vergi toplanması daha zorken, Doğu'daki latifundium çiftliklerinde yapılan küçük çaplı üretimden daha kolay vergi toplanabilmesi uygulama çeşitliliğini kanıtlayan durumlardandir. ${ }^{11}$

\section{Annona Civicia ve Annona Militaris Sistemi}

Geç Roma İmparatorluk sınırlarında yer alan bazı büyük ve/veya önemli kentlerin temel gida maddeleri açısından desteklenmesini sağlayan sistem (ya da uygulama) "annona civicia" sistemi olarak tanımlanmıştır. Bu sistem dahilinde, diğer eyaletlerden vergi karşılığında ayni olarak alınan ürünler söz konusu önemli/büyük ya da ihtiyacı olan kentlere aktarılmıştır; bu merkezlerin kentleşme sürecinin gıda temini ile bağlantılı olduğu anlaşılmaktadır. ${ }^{12} \mathrm{Bu}$ tip gıda ürünlerinin aktarıldığ 1 sanılan başlıca kentin, günümüz bilgileriyle başkent Constantinopolis olduğunu söylemek mümkündür. ${ }^{13}$ Constantinopolis'in, başkent olduğu süreçte inşa faliyetleriyle birlikte büyümekte olduğu ve üst tabakadan insanların buraya yerleştirildiği bilinmektedir. ${ }^{14}$ Büyüme faaliyetlerinin getirdiği bir gereksinim olarak yapılan gıda temini, hem üst sınıfa ait kişilerin hem de işgücü kesiminin buradaki varlığıyla doğrudan ilişkilidir. Kentteki yerleşmenin çoğalması ve kentin gelişimi için uygulanan teşvik uygulamalarından biri, kuşkusuz ki ücretsiz ekmek ve tahıl dağıtımıdır. Örnek bir hesaplama göz önüne alınarak; şehirde MS 5. yüzyılın ortasında 4388 ailenin oturduğu ve bunların yıllık 175.200

9 Mitchell 2016: 77-78, 245-247 ve 448. Geç Roma Dönemi’ndeki vergilendirme için, bkz: Hopkins 1980: $101 v d$.

10 Akdeniz'in Doğusu ve Batısı arasındaki farklı vergi kanun uygulamaları için bkz: Mitchell 2016: 248.

11 Kaçar 2005: 214-215. Latifundium: Roma İmparatorluk Dönemi'nde tarım üretimi yapan ve kölelerin çalıştığ 1 geniş çiftlik arazisidir.

12 Williams ve Friell 1999: 116.

13 Karagiorgou 2001: 154.

14 Gregory 2008: 67; Mitchell 2016: 444. 
ton buğdaya ihtiyaç duyduğu önerilmiştir. ${ }^{15}$ Diğer taraftan, günümüz araştırmalarının ortaya koyduğu üzere; tahılın tedarik edilen tek ürün olmadığ1, yağ ve şarap gibi başkaca temel gıda ürünlerinin de annona uygulaması kapsamında tedarik edildiği düşünülmektedir. ${ }^{16}$ Annona civicia kapsamında gıda tedariği yapılan șehirlerin içinde doğal ya da diğer afetlerle karşılaşanların da yer alması, bu tedariğin başka bir işlevini de ortaya koyar durumdadır. Örneğin, Edessa kentinde MS 499-501 yılları arasında yaşanan çekirge istilası sonucunda kente gönderilen yardım, bu tip bir uygulama olarak değerlendirilmektedir. ${ }^{17}$

Devletin diğer temel bileşeni olan askeriyenin sürekliliği de, en az kentlerin yaşaması kadar önemlidir. Annona militarisin, Geç Roma - Erken Bizans Dönemi ordusunun temel gida ihtiyaçlarının tedariğine yönelik oluşturulmuş bir uygulamalar bütünü olduğu ve askeriyenin asli tamamlayıcısı olarak işlediği düşünülmektedir. ${ }^{18}$ Temeldeki prensip, vergi karş1lığ toplanan ürünlerin askeriyenin temel g1da maddelerinin sağlanması için kullanılmasıdır. Batı Roma İmparatorluğu'nda işletilen gida tedariği modelinde, ordunun ihtiyaçlarının; yerelden, yerel eyaletten ve/veya diğer eyaletlerden geldiği ortaya konmaktadır. Bu bağlamda gerekli ürünlerin; yerel sivillerden vergi karşıllğında, devletin bedelini ödeyerek el koyması şeklinde ya da ticaret yoluyla temin edildiği bilinmektedir. ${ }^{19} \mathrm{Söz}$ konusu sistem, MS 2. yüzyılda ordu için misır toplama uygulamasiyken, ne zaman ve nasil bir vergi sistemine dönüștüğü ve/veya ne ölçüde dönüștüğü henüz bilinmeyen bir konudur. ${ }^{20}$ MS 3. yüzyılda yaşanan ekonomik kriz ve aşırı fiyat artışı neticesinde paralı işlemin tercih edilmemesi ve neredeyse yok olmasının; tüketici ve tüccar arasındaki alışverişin değiş tokuş yöntemiyle yapılması şeklinde sonuçlandığı düşünülmektedir. Öte taraftan, bu süreçte devletin de vergiyi ayni olarak toplayıp orduya göndermeyi tercih etmiş

15 Grant 2000: 19, 23. Tahıl temelli bir değerlendirme için ayrıca, bkz: Türe 2009: $115 \mathrm{vd}$.

16 Mitchell 2016: 444.

17 Mitchell 2016: 249-250.

18 Kaegi 1985: 591.

19 Carreras - Monfort 2002: 72vd. Akdeniz'in Batısında Roma İmparatorluk Dönemi başında ve devamında uygulanan annona sistemi için, bkz: Peacock ve Williams 1986: 54-66.

20 Wittaker ve Garnsey 1998: 277. olması, sistemin başlangıç noktalarından biri olmalıdır. ${ }^{21}$ Ayrıca, sistem uygulamalarından biri olarak gösterilen takasın nakde çevrilerek kullanılmış olması da, tercih edilen bir diğer pratik olarak ileri sürülmüştür. ${ }^{22}$ Söz konusu uygulamanın, MS 4. yüzyılda devletin gelirini artıran bir model olduğu önerilmektedir. ${ }^{23}$ Bununla birlikte, yiyecek ihtiyacının serbest ekonominin karar ya da "hevesler"ine bırakılamayacak kadar önemli olduğu düşüncesi, etraflıca değerlendirilmesi gereken bir öneridir. ${ }^{24}$

Askeriyede nakit maaş dışında günlük ihtiyaçların önemli bir kısmını gıda maddeleri oluşturmaktadır. ${ }^{25}$ Askerlerin günlük temel ihtiyacına bakıldığında ise, her bir askerin günlük iki sextarii ${ }^{26}$ tahıl ihtiyac1 olduğu kabul edilirse, her gün bir contubernium 27 askerin 16 sextarii (yani bir modius) ${ }^{28}$ tahıl tükettiği sonucuna ulaş1labilir. $\mathrm{Bu}$ hesaplama temel alınarak; Diokletianus'dan sonra genişletilmiş, 5.280 askerlik bir lejyon için günlük c.10.560 sextarii (660 modii) tahıla ihtiyaç duyulduğu tahmin edilmektedir. ${ }^{29}$ Askeriyenin ihtiyaç duyduğu temel gida maddelerine daha geniş bir hesaplama ile göz atıldığında; örneğin Constantinus döneminde Doğu'da hareketli kuvvet olan comitanseslerin c.100.000, sinır kuvveti olan limitaneinin ise c. 250.000 kadar oldu$\breve{g u}$ sanılmaktadır. ${ }^{30}$ İustinianus döneminde ise, Constantinopolis'de 70.000 askerin mevcut olduğu düşünüldüğünde, gereken gida ürünlerinin miktarı daha iyi anlaşlabilmektedir. ${ }^{31}$ Ancak mısır, şarap, zeytinyağ 1 , tahıl, sirke, et gibi temel gıda maddelerinin dışında, atlar için hayati ihtiyaç olan samanın da annona militaris ile tedarik

21 Haldon 2007: 59-60; Gregory 2008: 39.

22 Carrié 2012: 26.

23 Wittaker ve Garnsey 1998: 277.

24 Peacock ve Williams 1986: 58.

25 Geç Roma İmparatorluğu'nun tahmini devlet bütçe hesaplaması için, bkz. Treadgold 2015: 364.

26 Diokletianus'un "Fiyat Kararnamesi" temel alınarak: 1 sextarius ( $\xi \dot{\varepsilon} \sigma \tau \eta \varsigma)$ 0,546 l (1/6 congii); 1 İtalik sextari 0,547 l: Maria 2011: 366.

27 Contubernium: Roma ordusunda sekiz askerden oluşan en küçük birlik.

28 Modius; 16 sextariiye karşılık gelmektedir.

29 Roth 1994: 361-362.

30 C. Mango 2008: 41.

31 Prokopius, SH, 23. 24. Askeri nüfus hesaplamalar1 ve tartışmaları için, bkz: Jones 1964: 679-686; MacMullen 1980: 451vd; C. Mango 2008: 41-43; Mitchell 2016: 650-652. 
edildiği düşüncesi mevcuttur. ${ }^{32}$

Ordunun bulunduğu kalıcı garnizon merkezlerinde veya geçici konakladığ 1 yerlerdeki ihtiyaçlar1 bu sistem uygulamalarıyla giderilebiliyor olsa dahi, halkın da bir takım sorumluluklar taşıdığı bilinmektedir. Örneğin, İulianus'un MS 362 'de yaptığı doğu seferine hazırlık aşaması için kaldığ Antiokheia'da tahıl ihtiyacının yerelde giderilememesi nedeniyle şehirde yaşanan huzursuzluk ya da Edessa'daki askerlerin tükettiği ekmeğin üretiminde firıncıların yanı sıra halkın sorumluluk taşıması, bu tip uygulamaları kanitlar niteliktedir. 33

Yaşanan sınır problemleri nedeniyle Tuna ve k1yılarındaki askeri yerleşimler ve kaleler (limes) söz konusu gıda tedariğinin en yüksek ihtiyaç duyulduğu hatlardan birini oluşturmaktadır. Buradaki askeri yerleşimlerin ve dolayısıyla asker sayısının yüksek olması nedeniyle, bu bölgenin gıda ihtiyacının oldukça fazla olduğu düşünülmektedir. ${ }^{34}$ İlaveten, sinırlarda yaşayan ve kendilerine haraç ödenen Barbarların da Roma'dan gelen gida tedariğine sahip olduğu ve annona ile toplanan ürünlerle beslendikleri bilinmektedir. ${ }^{35}$

\section{Amphora Tipleri ve Üzerindeki Mühür ve Yazıtlar Bağlamında Annona Sistemi}

Yukarıda detaylandırılan tedarik pratiklerinin uygulanmasinda en önemli nakliye yolu denizaşırı nakliyedir. ${ }^{36}$ Deniz yoluyla yapılan taşı-

32 Kaegi 1985: 591; Carreras - Monfort 2002: 80.

33 Mitchell 2016: 115, 252.

34 Swan 2007: 251vd; Sarnowski 2015: v. 1, 279-290; Mitchell 2016: 548-549. Tuna kıyısındaki askeri yerleşimlerin Roma İmparatorluk Dönemi'ndeki dağıl1m1 için, bkz: Sarnowski 2015: vol. 1, Fig. 57-59.

35 Örneğin; Alaric ve adamları, olasılıkla ekim için uygun arazileri olmadığından, gıda tedariği için Roma Devletine bağımlıydılar. MS 399'da Claudianus'un, Alaric ve çevresinin erzak tedariğini sağlamakla görevli bir magister utriusque militiae olduğu bilinmektedir. Mitchell 2016: 139.

36 Denizaşırı her türlü nakliye işlemi navicularii (navi-

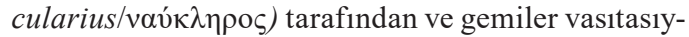
la yapılmaktayd1. MS 4. yüzyı1 sonrasında, navicularii ya da devlet temsilcisi tüccarların, gemi yapımı, tamirat1, mürettebat oluşturma ve tüm bu operasyonların finansmanını organize ettikleri bilinmektedir. Naviculariusların, serbest ticaretin yanı sira, Constantinopolis ve Roma kentlerine gida maddeleri nakliyesi gerçekleştirdikleri ve ordunun tedariğini sağladıkları bilinmektedir. Gemi veya kargoların zaiyatının devlet tarafından karşılanmış olmasının macılıkta ürünlerin taşınması için yararlanılan en önemli öğelerden birini ise amphoralar oluşturmaktadır. ${ }^{37}$ Ürünler amphoraların içine koyularak, amphoraların ağızları ürünün bozulmasını engelleyecek şekilde kapatılıp varış noktasına kadar ürüne eşlik etmektedir. Bu bağlamda, ürünlerin çıkış merkezinden ayrılırken, yolda ya da vardığ 1 yerdeki mevcudiyetleri amphoralar aracılığı ile izlenebilir; diğer bir deyişle söz konusu organik g1da ürünlerinin günümüze kalmış yegane somut izleri amphoralardır. ${ }^{38}$ İncelenen dönem içinde Akdeniz ve Karadeniz'de tespit edilen amphora çeşitliliğinin oldukça fazla olmasına rağmen, bunların içinden yalnızca bazı amphora tiplerinin annona için kullanıldığ 1 kabul edilmektedir. ${ }^{39}$ Antik kaynaklardan sistem ve/veya uygulamalarına dair açık ve ayrıntılı bilgilere ulaşılmamasına rağmen, günümüz araştırmacıları Doğu Roma İmparatorluğu'nda annona sisteminin uygulandığına ve bazı amphora formlarının da bu sistem içinde yer aldığına dair fikir birliği içindedir. ${ }^{40}$ Ancak, verilerin azlığ 1 nedeniyle hangi amphoranın, ne ölçüde annonaya hizmet ettiği ve hangi merkezlere tedarik sağlandığı konusunda birden fazla öneri mevcuttur. ${ }^{41}$ Söz konusu önerilerin geliştirilmesinde;

yanında, bir loncaları da mevcuttur. Bununla birlikte, MS 7. yüzyılda sadece kaptan ya da basit tüccar olarak çalıştıkları da anlaşılmaktadır. Kazdan 1991: 1441, "Naukleros".

37 Doğu Akdeniz'deki Roma İmparatorluk Dönemi ve Geç Roma - Erken Bizans Dönemi amphoraları için, bkz: Zemer 1978: 52-82; Riley 1979: 114-115, 145-236; Peacock ve Williams 1986: 1vd.; Bass 1982: 155-165; Hayes 1992: 61-71; Opait 2004: 6-43; Pieri 2005: 7vd.; Şenol 2009: 126-161; Şenol 2018: 18vd.; Bezeczky 2013: 25vd.

38 Peacock ve Williams 1986: 2; Cankardeş - Şenol 2005: 139-140; Şenol 2005: 133.

39 Çalışmada yer verilen dört amphora tipi dişında annona sistemi içinde yer aldığı sanılan başlıca amphora formlarına dair (LRA 4 ve LRA 5/6) bir inceleme için, bkz: Kingsley 2001: 53; Kingsley 2013: 130; Gerousi 2016: 131.

40 Gerousi 2016: 131; Reynolds 2018: 353vd. On iki adaların Geç Roma - Erken Bizans Dönemi ekonomisi ve annona sistemi içindeki yeri için, bkz: Deligiannakis 2008: 209vd. MS 5. yüzyılda, amphora ve diğer pişmiş toprak buluntu grupları temelinde iki farklı modelin (serbest ve devlet destekli) uygulandığına dair bir öneri de mevcuttur, bkz: Elton 2005, 693. Elton 2005: 693. Annona ve annona militaris'in operasyonel işlemleri hakkında, bkz: Kingsley ve Decker 2001: 1vd.

41 Başlıca öneriler için, bkz: Elton 2005: 692-69; Van 
amphoraların üretim dinamikleri, vardıkları merkezler, üretim ve kullanım özelliklerinin yanı sıra üzerindeki mühür ve yazıtlar (dipinti ve graffiti) da etkin rol oynamıştır. ${ }^{42}$ LRA 1, LRA 2, LRA 3 ve Zeest 80 amphoraları, bu dönemde annona sistemi içinde yer aldığ 1 sanılan tiplerden dördünü oluşturmaktadır. 43

İncelenen dört amphora tipine üretim merkezi ve dağılım alanları açısından bakıldığında; birbirinden farklı oranlarda olsa da, kitlesel ve seri biçimde üretildikleri anlaşılmaktadır. Ancak dağılımın nereye ve nasıl olduğu açısından bakıldığında ise; her amphora tipi için nispeten farklı sonuçlara ulaşılmıştır. ${ }^{44}$ Abidos Gümrük Vergisi yazıtı bu sistemi kanitlayan en önemli buluntulardan biri olarak kabul edilir. Yazıtta geçen "Kilikialı gemiciler" ifadesinin, LR 1 amphorası içinde Constantinopolis'e giden annona (annona civicia) şarabını taşıyan gemicileri işaret ettiği düşünülmektedir. ${ }^{45}$ Diğer taraftan, Constantinopolis ve bazı büyük şehirlerin annona civicia açısından desteklenmiş olmasına rağmen, LR 1 amphoralarının imitasyon üretimlerinin tüm (Doğu ve Batı) Roma İmparatorluğu'nda pazar ekonomisi içinde oldukça önemli bir konuma sahip olduğu da ileri sürülmüştür. Ayrıca bu öneri; kilise kurumunun ekonomik etkinliğinin bölgelere göre değişiklik göstermesi nedeniyle, şehirlerin ve ordunun ihtiyaçlarının sağlamasının yanı sıra, amphoranın kilisenin ihtiyaçlarına yönelik kullanılmış olabileceğini de içermektedir. 46 Öte yandan, kargosu LR 1 ve LR 2 amphoralarından oluşan Yassıada Batığı'nın da annona militarise hizmet eden kilise destekli bir gemi olduğuna dair öneri oldukça önemlidir. ${ }^{47}$ Yassıada Batığı kargosunun farklı atölyelerden toplanmış (LRA 1 ve LRA 2) amphoralardan oluştuğu tezi, yapılan analizler sonucunda kanıtlanmıştır. ${ }^{48}$

Doorninck 2015: 205vd.; Pieri 2012: 49; Brennan vd. 2020: 321-324.

42 Karagiorgou 2001: 149.

43 Ele alınan dört amphora tipi dosya çalışması niteliğinde seçilmiştir. Kara 2019: 4-5. Amphora tiplerinin adlandırmaları için bkz: Riley 1981: Fig. 10; Zeest 1960: $114-115$

44 Kara 2019: 212-225.

45 Iacomi 2010: 27-28, Fig. 9. “Abidos Vergi” yazıtı için, bkz: Durliat ve Guillou 1984: 581-598.

46 Pieri 2012: 48-49.

47 Van Doorninck 2015: 205vd.

48 Van Alfen 1996: 210; Leidwanger 2014: 899-901, Fig. 2a-d, 3a-c, 4a-c.
Buna göre, geminin olasılıkla Ege Denizi kökenli yükü buradaki bir depodan alıp Kilikia ya da Suriye'de bulunan bir (askeri) ihtiyaç noktasına götürüyor olması, araştırmaların ortaya koyduğu önemli bir sonuç önerisidir. ${ }^{49}$ Bunun dışında, LRA 1'den oluşan kargolara sahip çok sayıda batığın tespit edilmesi de, kitlesel aktarımı destekleyen unsurlardan biri olarak gösterilebilir. ${ }^{50}$ Amphoranın askeri garnizon ve merkezlerde yoğun olarak görülmesi ise, sözü edilen tedariğin varlığını kanıtlayan en önemli unsurlardandır. ${ }^{51}$

Çalışmada mühürler açısından yapılan değerlendirmede; çok az sayıda dini öğe (örn. haç) içeren mühür ve genellikle şahıs ve/veya yer isminin geçtiği monogramlar tespit edilmiştir (Fig. 1a). $\mathrm{Bu}$ tip içeriklerin görülmesi ve mühür oran/sayıları nedeniyle, LRA 1 mühürlerinin genellikle hakkındaki önerileri destekler şekilde, atölye ve/ veya sahibinin mühürü olabileceği sonucu ortaya çıkmaktadır. ${ }^{52}$ Diğer taraftan, basıldığı kenti temsil ettiğine dair öneriler değerlendirildiğinde, mühürlerin çok az sayıda ve kısa süreli basılması sebebiyle devam ettirilememiş bir gelenek denemesini temsil ediyor olabileceği sonucuna ulaş1lmıştır. ${ }^{53} \mathrm{Bu}$ bağlamda, söz konusu mühürler annona tedariği ya da onunla ilişkili bir kontrol mekanizmasından çok şahsi karar ve uygulamayı gösteriyor olmalıdır.

Dipinto ve graffito yazıtlar incelenerek ulaşılabilecek temel sonuç ise; bu yazıt biçimlerinin farklı gelişim, gelenek ve fonksiyona sahip olduğu yönündedir. LR 1 amphoraları üzerinde görülen dipinto yazıtlar çok sayıda ele geçmektedir ve içeriklerindeki çeşitlilik dikkate değer oranda fazladır (Fig. 1b). ${ }^{54}$ LRA 1'de görülen dipinto sayısı ve yayılım alanı, geniş ve yoğun yayılım gösteren bu formun buluntu sayısı ile paralel biçimde yüksektir. Yapılan karşılaştırma ve incelemeler sonucunda; LRA 1'in belirli bir gelişim

49 Leidwanger 2014: 901; Van Doorninck 1989: 205vd.

50 Çeşitli kargo örnekleri için bkz: Bass 1982: 155-165; Long ve Volpe 1998: 335-336; Minchev 2011: 145146; Öniz 2016: 39-40. Güncel bir araştırma için, bkz: Brennan vd. 2020: 291vd.

51 Karagiorgou 2001: 129vd.; Elton 2005: 693. LRA 1 dağılımı için, bkz: Şenol 2003: 82 (harita); Pieri 2005: 70-75, Fig. 32-33; Opait 2004: 8-10; Bezeczky 2013: 159; Alkaç 2015: Fig. 12.

52 Opait 2004: 9; Kara 2019: 47-51, 188-189.

53 Kara 2019: 188-189.

54 Kara 2019: 51-73. 
gösteren dipinto yazım geleneğinin olduğu, genellikle dini içerikli kısaltmalar ve kapasite yazılarından oluştuğu ve giderek amphora üzerinde daha geniş yüzeye yayılmış, birden fazla bilgi içeren yazıtlara dönüştüğü anlaş1 1 mıştır. ${ }^{55}$ Ek olarak, LRA l'in boyutsal anlamda çeşitliliği (mikro düzeyde boyutsal çeşitlilik) nedeniyle standardize olmadan üretilmiş olmasının, dipinto yazımını geliştirici etkilerden biri olduğuna dair öneri oldukça dikkat çekicidir. ${ }^{56}$ Diğer taraftan, dipintolarda görülen dini ifadelerin manastır ya da kilisenin yetiştirdiği ürünü sembolize ettiği ve/veya böyle bir dini kurumda yazılmış olduğu, ayrıca kilise ile üretim yönetimi arasındaki ilişkiyi gösterdiği de ileri sürülen düşüncelerdendir. 57 El yazılarındaki ve içeriklerdeki benzerliklerden yola çıkılarak, söz konusu yazıların dönem içinde toplu nakliye yapan birkaç büyük tüccar ya da naviculariusa işaret ediyor olabileceği anlaşılmaktadır. Ayrıca, LRA 1'de yer alan dipintoların ikincil kullanıma dair taşıdığı izler de, amphoraların yeniden ve aynı şekilde (olasılıkla aynı ürün taşınarak) yapılmış bir nakliyeye işaret etmesi nedeniyle oldukça dikkate değerdir. ${ }^{58}$

LRA 1 üzerindeki graffitoların oldukça az sayıda tespit edilmesi, yeniden ele alınması gereken konulardan birini ortaya çıkarmıştır. Bu bakımdan, Yassiada Batığı'ndan gelen graffitolar bilinen diğer örnekler içinde önemli bir orana sahiptir. 59 Söz konusu grafftoların taşınan ürünü ve/veya ikincil kullanımı işaret eder yazıtlar olduğu ileri sürülmüştür. ${ }^{60}$ Ancak yapılan incelemeler ile, hem bu yazıtların hem de diğer tüm LRA 1 graffitolarının herhangi bir geleneği yansitmayan münferit örnekler olduğunu söylemek mümkündür. ${ }^{61}$ İlaveten, tüm LRA 1 yazıt ve mühürlerinin dikkat çeken bir başka özelliği ise, bu amphora formu üzerindeki graffito, dipinto ve mühürlerin, genellikle aynı anda bir amphora üzerinde görülmemesidir. ${ }^{62} \mathrm{Bu}$ durum, bir uygulamanın

55 Kara 2019: 51-73.

56 Fournet ve Pieri 2008: 177; Kara 2019: 205-206.

57 Derda 1992: 140; Pieri 2007: 612.

58 Fournet ve Pieri 2008: 195, dipnot: 42; Kara 2019: 189.

59 Kara 2019: 73-75. Yassıada Batığı'nda görülen graffitolu LRA 1 örnekleri için bkz: Van Alfen 1996: 202; Van Doorninck 1989: 250; Van Doorninck 2015: 207.

60 Bass 1982: 165.

61 Kara 2019: 190.

62 Kara 2019: 47-75. diğerinin yerine geçtiğini göstermese de, birbirini tamamlayan ifadeler olmadığı sonucunu ortaya koyar niteliktedir.

İkinci form olan LR 2 amphoraları, Tuna çevresindeki kale ve askeri yerleşimlerde siklikla ele geçmiş ve annona militaris sistemi içinde buraya geldikleri ileri sürülmüştür. ${ }^{63}$ LR $2 \mathrm{C}$ (LRA 13) amphora tipinin üretim merkezlerinden bazılarında yapılan araştırmalar, söz konusu amphoraların sistem içindeki yerine dair ipuçları vermektedir. Halasarna'daki (Kos Adasi) LRA 2C (LRA 13) üretiminin dışında, yine Kos Adası'nda yer alan Kardamaina ve Mastikhari'de MS 7. yüzyılda yapılan amphora üretiminin de, benzer şekilde Constantinopolis ve ordunun tedariğini sağlayan annona sistemine yönelik olduğu önerilmektedir. Ek olarak Paros Adası'nda yapılan araştırmalar, buradaki MS 6. ve 7. yüzy1llarda (MS 536'da quaestura exercitus biriminin kurulmasının ardından) gerçekleşen amphora üretiminin annona sistemine hizmet ettiğine dair bir sonuç önerisi ortaya çıkarmıştır. ${ }^{64}$ Diğer taraftan, LRA 2'nin LRA 1 ile benzer bir üretim ve dağ 11 เm yoğunluğuna sahip olduğu oldukça açıktır. ${ }^{65}$ Bu tiplerin (LRA 1 ve LRA 2) benzer ama eşit olmayan oranlarda ele geçmesinin; iki amphora arasındaki hacimsel farktan kaynaklandığı, aslında eşit ölçülerde ürün dağıtımı yaptıkları düşünülmektedir. ${ }^{66}$ Ancak LRA 2'de görülen mühürler için, LRA 1 mühürlerinki ile benzer bir sonuca ulaşmak mümkün değildir. LRA 2 mühürlerinin, gerek içeriği gerekse basım uygulamaları çok basılmamış ve uzun süre kullanılmamış bir gelenek çabasını gösterse de; üretime devlet müdahalesi/kontrolü gibi bir organizasyonun varlığına işaret eder niteliktedir. LRA 2 üzerindeki mühürlerin içeriği göz önüne alınarak, kilisenin üretime katıldığgıa dair bir öneri de sunulmuştur. ${ }^{67}$ Mühürlerin birden fazla çeşitte içeriğe sahip olmasının aksine, büyük çoğunluğunu elinde scepter ve mappa tutan ve genellikle ikili basılan "takım mühür"leri oluşturmaktadır (Fig.

63 Karagiorgou 2001: 129vd.

64 Diamanti 2016: 691; Didioumi 2014: 172; Diamanti 2015: 541-43. Quaestura exercitus biriminin kurulması ile annona sisteminin resmiyet kazandığına dair güncel bir açıklama için, bkz: Brennan vd. 2020: 174.

65 Riley 1979: 418; Şenol 2003: 96 (harita).

66 Şenol 2009: 152.

67 Diamanti 2010: 209. 
2a-b). ${ }^{68}$ Yapılan inceleme ve karşı1laştırma yard1miyla, söz konusu mühürlerin ve benzerlerinin basım geleneği ve mühür tasarımı açısından uyumlu oldukları anlaşılmıştır. Diğer taraftan, "takım mühürler"in içindeki ilk ve ikinci mühürün çapraz karşılaştırması sayesinde, küçük form değișikliklerine sahip birbirinden fark11 değerlendirilebilecek amphoraların aynı tip içinde incelenmesi ve kronolojilerin de yeniden değerlendirilmesi gerektiği ortaya çıkmaktadır. Tüm bu sonuçlarla birlikte, takım mühürler, söz konusu devlet kontrolünü temsil eden mühür biçimi olarak yorumlanmıştır. ${ }^{69}$ Bunun dışında, günümüz araştırmaları 1şı̆̆ında sadece Constantinopolis'de ele geçen haç monograml1 bir mühürün varlığı da başkente gelen özel ya da tek partilik bir ürünü ve/veya nakliyeyi gösteriyor olmalıdır. Bu bağlamda, sadece Constantinopolis'de ele geçen böyle bir buluntunun varlığg da annona sistemindeki tedariğin yansıması olarak değerlendirilebilir. ${ }^{70}$

LRA 2 üzerinde görülen dipinto yazıtların LRA l'dekiler kadar yaygın biçimde ele geçmediği bilinmektedir. Organik mürekkeple yazıldığ korunagelmemesine rağmen, yapılan incelemeler ile LRA 2 dipinto yazilarının LR 1 amphoralarındaki kadar çokça kullanılmadığı anlaşılmıştır. Ancak, dipinto yazım ve gelişim geleneği açısından, LRA 1 dipintoları ile benzerlik gösteren özelliklere sahiptir ve bazı yazıt içeriklerinin de oldukça benzer olduğu sonucuna ulaşmak mümkündür. Yazitlarda, dini sembol ve içerikler, kapasite göstergeleri, kapasite değerleri, ürünün geldiği ve varacaği yer ile ilgili olduğu sanılan ifadeler ve k1saltmalar mevcuttur (Fig. 3a-b). ${ }^{71}$ LRA 2 üzerindeki bazı ifadeler, LRA 1 üzerinde görülenlerle ortaklık içermektedir. Söz konusu yazıların bir yazım geleneğini gösterdiği, bazı yazıların aynı elden/merkezden yazılmış olduğu ve/veya büyük çaplı nakliye yapan tüccar/naviculariusi işaret ettiği düşünülmektedir. ${ }^{72}$

Graffito yazıtlar incelendiğinde, Yassıda Batığı'nda ele geçen LR 2 amphoralarının

68 Kara 2019: 88-100.

69 Sztetyło ve Borkowski 1986: 650; Opait ve Diamanti 2014: 55-56, 59; Papanikolaou 2014: 172, 186; Kara 2015: 245, vd.; Kara 2019: 88-100, 190.

70 Kara 2019: 100-101, 191, Kat. No. 83, 84, 85, 86 ve 87.

71 Kara 2019: 105-121.

72 Kara 2019: 212. üzerindeki graffitoların ikincil kullanıma işaret ettiğine dair öneri oldukça önemlidir. ${ }^{73}$ Ancak, LR 1 amphoralarının tersine graffitolu LRA 2 sayısı oldukça fazladır. Akdeniz ve Karadeniz çevresindeki merkezlerde ele geçen LRA 2'lerde dikkat çekici oranda graffito yazılara rastlanmaktadır, ancak bu yazıtlar kısıtlı bir içeriğe sahiptir. Graffitolarda; dini öğelerin yanında, şahıs ismi ve kapasite ifadesi olduğu sanılan kısaltma ve açık yazı graffitoları ile karşılaşılmıştır (Fig. 4). ${ }^{74}$ LRA 2 'ler üzerindeki yazitların oranlaması bu bağlamda dikkat çekicidir. Yukarıda da bahsedildiği gibi dipintoların korunagelmemesi gibi bir durum bilinmesine rağmen, bu amphora tipinde dipintonun graffitoya göre daha fazla kullanıldığını söylemek günümüz bilgileri 1şı ğında oldukça zordur. ${ }^{75}$ Bu bağlamda LRA 2 graffitoları yeniden değerlendirildiğinde, tüm ele geçen LRA 2 graffitolarının ikincil kullanımı gösterdiği düşüncesini yeniden ele almak gerektiği ve belki de bazen birincil kullanımda tercih edilen yazının graffito olduğu sonucuna ulaşılmaktadır. ${ }^{76}$

Üçüncü amphora tipi olarak incelenen ve Ege üretimli bir form olduğu bilinen LR 3 amphorasının, söz konusu tedarik sistemi içinde kullanılmış olabileceğine dair bir öneri ileri sürülmüştür. ${ }^{77}$ Amphoranın tüm Akdeniz ve Karadeniz’i içine alan geniş bir alanda dăğllım gösterdiği kanıtlanmış olmasina rağmen, LRA 1 ve LRA 2 amphoraları kadar yaygın ve yoğun ele geçmemektedir. ${ }^{78}$ Bununla birlikte, Constantinopolis'e de LRA 1 ve LRA 2'ye göre daha az oranda geldiği anlaşılmaktadır. ${ }^{79} \mathrm{Bu}$ durum başlıca bilinen LRA 3 üretim merkezleri olan Ephesos ve Kos Adası'ndan başkente gelen desteğin boyutunu sorgular niteliktedir. Özellikle Tuna kıyılarındaki askeri yerleşimlerde de az sayıda ele geçmesi, toplu bir aktarım yapılmadığını göstermekte ve annona militaris sistemi içinde kullanılmış olma ihtimalini zayıflatmaktadır.

73 Van Doorninck 1989: 247-253; Pieri 2005: 93.

74 Kara 2019: 121-129.

75 Kara 2019: 192.

76 Kara 2019: 205.

77 Ladstätter 2011: 23.

78 LRA 3 dağılımı için, bkz: Pieri 2005, 99, Fig. 62; Bezeczky 2013: 33, Fig. 24-26.

79 Hayes 1992: 63, Type 3. Küçükçekmece Göl Havzas1 (Bathonea?) ve İstanbul'daki diğer kazılara dair çıkarımlar yazarın şahsi gözlemleridir. 
Diğer taraftan, kargosu LR 3 amphoralarından oluşan bir batığın şu ana kadar tespit edilmemiş olması da, LR 3 amphoralarının burada bahsedilen diğer amphora formları (LRA 1, LRA 2 ve Zeest 80 ) gibi kitlesel nakliyesinin yapılmadığııın göstergesi olarak kabul edilebilir. ${ }^{80}$ LRA 3'ün ele geçtiği merkezler ve üretim alanı olan Ephesos'da yapılan çalışmalar ile, çağdaşı olan aynı (olasılıkla şarap) ürünlerden daha kıymetli ve pahalıya satılan bir ürün çeşidi taşıdığı önerilmiştir. ${ }^{81}$ Ephesos'da toplanan vergiler karşılaştırıldığında, şarabın katma değerinin zeytinyağ 1 ve nakit vergiden daha yüksek olduğu bilinmektedir. ${ }^{82}$ LR 3 amphoralarının küçük boyutlu ve görece kaliteli bir şarap taşıyor olması ya da bu algıyı temsil etmesi, ordunun desteğinden ziyade, askerlerin şahsi (lüks/yarı lüks) harcamalarına yönelik ya da sınır bölgelerindeki tüketime (Vandallar, Hunlar, vb.) hitap edecek pazarlara gönderiliyor olduklarını akla getirmektedir. ${ }^{83}$ Nitekim, güneydeki bir askeri merkeze tedarik olarak yola çıtı̆̆ 1 sanılan ve sadece LRA 1 ve LRA 2'den oluşan kargoya sahip Yassıada Batığı'nda yalnızca bir adet LR 3 aphorasının görülmesine de bu noktada değinmek gerekir. ${ }^{84}$ LR 3 amphorasının Kartaca kazılarında yoğun ele geçtiği en erken dönem ise, Vandalların bölgede hakim olduğu yıllara (MS 475-500) işaret etmektedir. ${ }^{85} \mathrm{Bu}$ veriler 1şı̆̆ında; LRA 3'ün annona ve annona militaris sistemi içinde kullanıldığ 1 kabul edilirse, Roma İmparatorluğu'nun vergi karşı1lığı bu ürünleri alıp, söz konusu pazarlara lüks ürün olarak göndermesi ve karşılığında nakit kazanımı sağlaması yoluyla olabileceği düşünülmektedir. ${ }^{86}$ Çalışmada hipotetik olarak önerilen bu yöntem, Roma İmparatorluğu'nun kuzeyde barışın devamlılığı için verdiği haracın, bu pazarlar yoluyla yeniden nakde çevrilerek Roma devletine geri dönmesinin sağlanmış olabileceğine yöneliktir. Söz konusu önerinin doğru olduğu kabul edildiğinde, ilkel takasa dönüşmeden yapıldığı önerilen ürün-vergi toplama/dağıtma sistemi önerisinde

80 Kara 2019: 209.

81 Lauffer 1971: 218, 2. 13-14; Hayes 1992: 434, dipnot: 9.6; Maria 2011: 371, 2. 14; Kara 2019: 220.

82 Bezeczky 2013: 25.

83 Karşılaştırma için, bkz: Csiky ve Magyar - Harshegyi 2015: $175 \mathrm{vd}$.

84 Sözü edilen LR 3 amphorasının, geminin kilerine ait olduğu düşünülmektedir: Bass 1982: 183, P74.

85 Peacock 1984: 121.

86 Kara 2019: 209, 221. yer alan "bir şekilde nakde çevirme" ihtiyacının giderilmiş olabileceği ileri sürülebilir. ${ }^{87}$ Bununla birlikte, LR 3 amphorasının serbest ticaret kapsamında kullanıldığ 1 (yukarıda bahsi geçen diğer amphora tipleri gibi) da unutulmamalıdır. ${ }^{88}$ Bunlara ek olarak, çalışmada ulaşılan sonuçlar doğrultusunda, Tuna kıyılarında ve kuzeyde ele geçen LR 3 amphoraları için yapılan "sipariş doğrultusunda getirilme" önerisinin de yeniden değerlendirilmesi gerektiği düşünülmektedir. ${ }^{89}$

LRA 3 üzerindeki mühürlerin ortaya koyduğu sonuçlar ise, LRA 1 sonuçları ile benzerlik göstermiştir. Oldukça az sayıda karşılaşılan LRA 3 mühürlerinin şahsi ya da atölye bazlı mühür basım denemelerini yansıttığı ve basımın gelenekleşmemiş olduğu anlaşılmaktadır (Fig. 5a). ${ }^{90}$ Dipinto ve graffito yazım örnekleri de yine oldukça az sayıda tespit edilebilmiştir. LR 3 amphoralarında görülen graffito yazıtların da mühür örnekleri gibi gelenekleşmiş ya da toplu aktarımı gösteren örnekler değil, onun yerine denizaşırı ticareti gösteren ikincil kullanımdan çok, genellikle yerelde kullanılmış saklama kabı ya da sahiplenme amaçlı yazılmış yazılar olabileceği sanılmaktadır. Dipinto yazıtlardan ise, az sayıda olmasına rağmen denizaşırı aktarıma ilişkin bazı bilgiler edinmek mümkündür (Fig. 5b). Ancak buluntu merkezleri ve ele geçen örnekler incelendiğinde, bu yazıtların korungelmemelerinin yanı sıra çokça tercih edilmedikleri de anlaşılmıştır. ${ }^{91}$ Ele geçen örneklerin arasında toplu aktarımı gösterecek az sayıda örnek ile karşılaşılmaktadır. Söz konusu örneklerin yazıt içeriğinden yola çıkılarak; özellikle LRA 1 ve LRA 2'de yer alan aklamasyon formülüne sahip LR 3 amphoralarının, diğer amphora tiplerinin toplu gönderimi içinde yer aldığ 1 düşünülebilir. ${ }^{92}$ Bu bilgiler 1ş1ğında, bahsi geçen münferit dipinto örnekleri dışında, LRA 3 üzerindeki mühür, dipinto ve graffito yazılarında toplu aktarım ya da tedariğe yönelik kullanıldığına dair herhangi bir bulgu mevcut değildir. Varılan bu sonuç da, yukarıda

87 Carrié 2012: 22-26.

88 Bezeczky 2013: 25.

89 Kara 2019: 210. Söz konusu öneri için, bkz: Karagiorgou 2001: 153.

90 Kara 2019: 212.

91 Kara 2019: 138-145, 194, 215.

92 Aklamasyon dipintosuna sahip LRA 3 örneği için bkz: Pieri 2005: 101, Pl. 28. 2, Pl. 78. 5a-b. 
bahsi geçen çıkarımları destekler nitelikledir. ${ }^{93}$

Tedarik sistemi açısından incelenen dördüncü ve son amphora ise Zeest 80 amphorasıdır. ${ }^{94}$ Roma İmparatorluk Dönemi'nin başlarında Akdeniz ve Ege yerleșimlerinde nadir, Karadeniz merkezlerinde ise daha yoğun görülürken, Geç Roma Dönemi'ne gelindiğinde nispeten değişikliğe uğramış bir formla ve daha kısıtlı bir coğrafyada karşımıza çıkmaktadır. ${ }^{95}$ Akdeniz'de MS 5. yüzyıldan sonra ele geçmemesi ve Tuna sınırındaki merkezlerde MS 5. yüzyıl sonu - 6. yüzyıl başında azalması/kaybolması oldukça dikkat çekicidir. ${ }^{96}$ Ancak yapılan çalışmada ortaya çıkan bulgular 1şığında, MS 6. yüzyılda ve hatta olasılıkla 7. yüzyıl başında/ortasında (?) da üretiminin devam ettiği önerilmiştir. ${ }^{97}$ Güney Marmara k1yılarında üretildiğine dair öneri, hem mühür ve yazıtlar hem de buluntu yerleri açısından, burada sunulan çalıșmanın sonuçlarıyla paralellik gösterir durumdadır.98 Çalışmada elde edilen verilerden ulaşılan diğer temel sonuç ise; Zeest 80 amphorasının Tuna çevresindeki yoğunluğunun yanı sıra, Constantinopolis'in de oldukça önemli bir teslimat merkezi oluşudur. Eldeki veriler 1şığında, bahsi geçen coğrafya dışında geç dönem alt tipi olduğu ileri sürülen formun (MS 6. yüzyıl - 7. yüzyıl başı/ortası?) ele geçmemesi

93 Kara 2019: 209, 214-215.

94 Opait: baskıda.

95 Zeest 80 amphorasının tipolojik gelişim ve dağ1lımı için, bkz: Zeest 1960: 114-115; Scorpan 1977: 278, Fig. 13, 15; Riley 1979: 118-119, Fig. 33, Fig. 83. D240, 84, D. 241; Opait 1987: 24-250; Swan 2010: 112-114; Hayes 1992: 63, tip 4; Kara 2019: 146-150.

96 Swan 2010: 114-115.

97 Kara 2019: 149, 217. Geç dönem formlarından biri olduğu sanılan örnekler için, bkz: Hayes 1992: 63, type 4.

98 Örneğin; Kara 2019: Kat. No: 208-210, 236. V. Swan, N. Günsenin'in Marmara Adası'nda bulunan metamorfik, mika, kalker ve diğer katkı maddelerini içeren kile dikkat çekmesi sebebiyle, üretim yerinin bu bölgede aranabileceğine işaret etmiştir: Swan 2010: 114; Opait: baskıda. Bandırma ve Bursa kıyısından ele geçen amphora örneklerinin yukarıda bahsi geçen forma benzerliği de dikkat çekicidir: Gündüz 2017: 100, fotoğrafta sol-üst; Dumankaya 2018: Fig. 7 - sol. Çalışmada, Zeest 80 amphorasındaki tüm yazıt ve mühür gruplarındaki ortak bulgulardan hareketle Zeest 80'in üretim alanı için bir öneride bulunulmuştur. Buna göre, amphoranın üretim yeri/yerlerinin Güney Marmara'da yer alan Agapios Manastırı ve çevresinde aranması gerektiği önerilmektedir. Kara 2019: 198-199. ise; bu olası geç Zeest 80 amphorasının ağırlıklı olarak Constantinopolis ve çevresine gönderilmiş ya da sadece burası için üretilmiş bir tedarik amphorası olduğunu düşündürmektedir. Zeest 80 amphorasının Geç Roma - Erken Bizans Dönemi'nde Tuna çevresinde ve Akdeniz'de yok olurken, Constantinopolis ve Marmara çevresinde yoğunlaştı̆̆ına dair kanıtlar, annona sistemi içinde kullanıldığına dair görüş açısından oldukça önemlidir. ${ }^{99}$

Zeest 80 amphoralarındaki mühürlerin sayısı amphora oranına göre yoğun değildir, ancak içerik açısından oldukça çeşitlidir (Fig. 6a). ${ }^{100} \mathrm{Bu}$ durumun, farklı atölye ya da yöneticilerden (kilise/manastır, vb.) kaynaklı olabileceği düşünülmektedir. Ancak her iki durumda da; kilise kurumunun üretim ve/veya kontrolde oldukça etkin rol oynadığ1 sanılmaktadır. ${ }^{101} \mathrm{Bu}$ sonuca ulaşmada en önemli etken; mühürlü amphoraların buluntu yerleri kadar, mühürlerin içeriklerindeki baskın Hıristiyanlık öğeleridir. Söz konusu dini ifadelerden yola çıkılarak, bunların kilise merkezli bir kontrol sisteminin göstergesi olabileceği ileri sürülmüştür. ${ }^{102}$ Zeest 80 mühürlerinin, MS 4. yüzyıl ortasi/sonundan sonraki yıllarda atölyelerde söz sahibi olan kurumların bir nevi markalaşmaya gittiği ya da atölyelerin üretim ve dağıtımının devlet/kilise görevlileri tarafından kontrole tabi olmaya başlaması ile ilișkili olabileceği önerilebilir. ${ }^{103}$

Diğer taraftan Zeest 80 amphorasının dipintoları da, daha önce karşılaşılan LRA 1, LRA 2 veya LRA 3 dipintoları ile hem yapisal hem de içerik anlamında farklılıklar göstermektedir. Kendi içindeki yazım geleneği ve gelişimi takip edilebilmesine rağmen, yapılış fonksiyonun nispeten farklı olduğu sanılmaktadır. El yazısı tekniğinden uzak, çoğunlukla komplike biçimde hazırlanmış blok monogram ya da açık kısa yazıtlarla karşılaşılmıştır. Oldukça yoğun olarak görülen Hıristiyanlık öğeleri tıpk1 mühürlerdeki gibi baskın bir yoğunluğa sahiptir. ${ }^{104}$ Öte taraftan, graffitolar için aynı durumdan bahsetmek daha zordur. Kulbun altındaki

99 Swan 2010: 114; Kara 2019: 148-149.

100 Kara 2019: 150-161.

101 Kara 2019: 195, 211, 222.

102 Opait: baskida.

103 Kara 2019: 195.

104 Kara 2019: 162-167, Kat. No. 227-230. 
boyun yüzeyine yazılmıș olan ve kapasite ifadesi olabileceği sanılan kısa yazıtların dışında herhangi bir gelenekleşmiş graffito yazıtı ile karşılaşılmamıştır. Graffitoların önemli bir çoğunluğu post-cocturam yazılmıştır. Elde edilen veriler 1şığında, graffito içeriklerinin kapasite gibi fonksiyonel yazıtlarla başlayıp devamında, bazı dini öğe ve monogram içeren graffitoların da yazıldığ 1 anlaşılmaktadır (Fig. 6b). ${ }^{105}$ MS 5. yüzyıla tarihlendirilen Lazuren Bryag Batığı'nda (Varna/Bulgaristan) görülen Zeest 80 amphoraları genellikle birden fazla graffitiye sahiptir; bu graffitoların farklı iki ifadeyi temsil ettikleri ya da amphoranın ikincil kullanımını gösterdiğine dair bir öneri mevcuttur. ${ }^{106}$ Sayıya işaret edebilecek söz konusu iki graffitolu örneklerin bazılarında; gösterdikleri sayı değerleri birbirinden önemli ölçüde farklı olduğundan (aynı ölçü birimi ile doldurulduğu kabul edildiğinde), söz konusu yazıların ikincil kullanım yerine, amphoranın içeriği, tüccarı, çıkış ya da varış yeri ile ilgili olabileceği de sanılmaktadır. 107

\section{Değerlendirme}

İncelenen tüm Geç Roma - Erken Bizans (LRA 1, LRA 2, LRA 3 ve Zeest 80) amphoralarındaki mühür (epigrafik ve anepigrafik) ve yazıt örnekleri temel alınarak; neredeyse tümünde işlenen din temalı öğe, ifade ve sembollerin, üretici (fabrikant veya ürün yetiştiricisi)/kontrolör ve/veya taşıma aşamalarınından en az birinin kilisenin müdahilliğinde gerçekleştiği önerilebilir. Çalışmada mercek altına alınan amphoraların üretim/dağ1$11 \mathrm{~m}$ yerleri ile mühür ve yazıtların tipolojik inceleme ve karşılaştırmaları, dönemin üretim modeline/modellerine dair kanitlar sunmaktadir. Devletin üretimdeki kontrolü yoğun biçimde hissedilmektedir ve bunun yanı sıra devlet destekli üretimin kanıtlarının varlığı da yadsınamaz durumdadır. Annona civicia ve annona militaris kullanımı açısından ise, gıda tedariği yapılan merkezlerdeki (Örn. Tuna kıyıları, Constantinopolis, vb.) dipinto ve mühür oranlarının paralelliği, gıda temini ile amphora tipleri aralarında bir bağlantı olduğuna dair ipuçları vermektedir. Ancak bu aşamada açıklanamayan konulardan

105 Kara 2019: 167-172, Kat. No. 232-246.

106 Birden fazla graffiti taşıyan Zeest 80 amphoralarının yeniden kullanıldığına dair öneri için: Minchev 2011: 148.

107 Kara 2019: 197. biri; kilise kurumunun ve devletin, üretim ve dağıtım organizasyonunda nerede durdukları ve ne kadar müdahil olduklarıdır (Fig. 7). ${ }^{108}$ Ek olarak, kilisenin de tedarik yapılan yerlerden biri olarak ele alınması gerekmektedir. Yapılan incelemeler bütüncül bir çerçevede ele alındığında; yoğun ve baskın biçimde görülen dini öğeler, devletin takip edilebilir izleri ve tam anlamıla gelenekleşmiş ya da standartlaşmış mühür ve yazıtlarla bazı amphoralarda karşılaşılması; hem şahsi kararları, hem devletin müdahalesi/desteğini, hem de kilise/manastır kurumunun aynı anda bu süreci tamamladığını düşündürmektedir. Diğer bir deyişle kilise, devlet ve tüccar/naviculariusun ana uygulama birimlerini oluşturdukları sonucunu ortaya çıkarmaktadır. Bununla birlikte, sözü edilen unsurların katılım oran ve uygulamaları Diokletianus'dan Heraklius'a kadarki süreçte değişim gösterse de sistemin çok ciddi farkl11ıklar geçirmediği anlaşılmıştır. Bu bağlamda, ürün ve amphora üretimi, depolanmas1, mühürleme ve/ veya yazıtların yazılma işi, nakliyesi gibi tüm işlem basamaklarında ya da bunlardan biri, birkaçı ya da hepsini kapsayan bir tedarik zincirinin olup olmadığı konusunda henüz aydınlatılamamış pek çok nokta olmasına karşın, söz konusu mühür ve yazıtlar ve bunların bir bütün içinde incelenmesi ile elde edilen verilerin, bahsi geçen işlem basamakları içindeki bilinmeyen boşlukları açılamaya yardımcı olabileceği oldukça açıktır. Bununla birlikte, daha sağlıklı ve aydınlatıcı analizler yapabilmek için, diğer bilinmeyen konuların yanı sıra bu döneme ait amphora, yazıt ve mühürler hakkında daha fazla bilgiye ve istatistiğe ulaşılması gerektiği düşünülmektedir. İleride yapılacak araştırmalarda, sözü edilen döneme ait ilgili buluntu ve bulguların serbest ticaret ve tedarik açısından her iki olasılık temelinde incelenmesi gerekmektedir.

\section{Teşekkür}

Makale, “Geç Antik Çağ’da (M. S. 4. - 7. yüzyıl) Doğu Akdeniz'de Üretilen Ticari Amphoralarda Dipinti, Graffiti ve Mühür Kullanımı" başlık11 tezde ortaya konan sonuçların güncel olarak değerlendirilmesidir. Söz konusu tez, Ege Üniversitesi, Sosyal Bilimler Enstitüsü, Arkeoloji Anabilim Dalı'nda (Klasik Arkeoloji Bilim Dalı) tamamlanmış olup ve Koç Üniversitesi Suna \&

108 Kara 2019: 210. 
İnan Kıraç Akdeniz Medeniyetleri Araştırma Merkezi tarafından KU AKMED 2018/T.1047 numaralı proje ile desteklenmiştir. Söz konusu kuruma destekleri için teşekkürlerimi sunmak isterim.

\section{Kisaltmalar}

$l$ litre

MS Milattan sonra

\section{Kaynakça}

Van Alfen 1996: P. G. van Alfen, "New light on the 7th-century Yassi Ada shipwreck. Capacities and standard sizes of LRA 1 amphoras", JRA, 9. 189-213.

AlKAÇ 2015: E. Alkaç, "Kanytellis Kazısından Late Roman 1 Amphoraları", (ed.Ü. Aydınoğlu) Kanytellis (Kanlıdivane): Dağllk Kilikya'da bir kırsal yerleşimin arkeolojisi, İstanbul, 149-157.

Bass 1982: G. F. Bass, "Pottery”, (eds. G. F. Bass, F. H. Doorninck). Yassı Ada. College Station, 155-189.

Bezeczky 2013: T. Bezeczky, P. Scherrer, R. Sauer, The amphorae of Roman Ephesus, Wien.

Brennan vd. 2020: M. Brennan, D. Davis, A. Opaiț, M. Stay, "Deep-water shipwrecks in the East Mediterranean: A microcosm of Late Roman exchange", JRA, 33, 291-329.

Bowman 2018: A. K. Bowman, "The State and the Economy: Fiscality and Taxation", Trade, commerce, and the state in the Roman world, 27-52.

CANKARdeŞ-ŞEnOL 2005: G. Cankardeş-Şenol, "Amphora Mühürlerinin Köken ve Sosyal Statünün Belirlenmesindeki Etkileri ve Kent Lokalizasyonun Tespitine Katk1ları", OLBA, 12, 139-164.

CAnKardeş-Şenol 2015: G. Cankardeş - Şenol, “Smyrna Kazılarında Ele Geçen Amphora Mühürleri: İlk Gözlemler", (eds. A. Ersoy, G. Şakar), Smyrna/ İzmir Kazı ve Araştırmaları: I. Çalıştay Bildirileri, 235-241.

Carreras-Monfort 2002: C. Carreras - Monfort, "The Roman military supply during the Principate: Transportation and staples", The Roman army and the economy, 70-89.

CARrié 2012: J. M. Carrié, "Were Late Roman and Byzantine Economies Market economies?", (ed. C. Morrisson) Trade and markets in Byzantium, Washington, D. C., 13-26.

CSIKy ve Magyar-HÁRshegyi 2015: G. Csiky, P. MagyarHárshegyi, "Wine for the Avar elite? Amphorae from Avar period burials in the Carpathian Basin", The Danubian Lands Between the Black, Aegean and Adriatic Seas (7th century BC-10th century AD), (eds.) G. R. Tsetskhladze, A. Avram, J. Hargrave, Proceedings of the Fifth International Congress on Black Sea Antiquities (Belgrade - 17-21 September
2013), 175-182.

Çiвuk 2019: K. Çibuk, Kocaeli Müzesi Amphora Koleksiyonu, Kocaeli Üniversitesi, Sosyal Bilimler Enstitüsü, Kocaeli (Yayınlanmamış yüksek lisans tezi).

Deligiannakis 2008: G. Deligiannakis, "The economy of the Dodecanese in late antiquity", (eds. C. Papageorgiadou - Banis, A. Giannikouri),

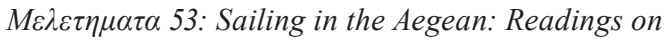
the economy and trade routes, 209-233.

DERDA 1992: T. Derda, "Inscriptions with the Formula

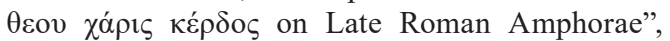
ZPE, 94, 135-152.

Diamanti 2010: C. Diamanti, Local production and import of amphoras at Halasarna of Kos island (5th-7th c.): Contribution to the research of the production and distribution of the Late Roman/ Proto-Byzantine amphoras of the Eastern Mediterranean, Atina. (Yunanca)

Diamanti 2015: C. Diamanti, "Amphora Production at the Aegean Sea during the 5th-7th Centuries", The Case of a Workshop at Paros Island: Preliminary Results, Tourner autour du pot: Les ateliers de potiers médiévaux du Ve au XIIe siècle dans l'espace européen : actes du colloque international de Douai (5-8 octobre 2010), Caen, 541-545.

Diamanti 2016: C. Diamanti, "The Late Roman Amphora Workshops of Paros Island in the Aegean Saea" REI Acta, 44, 691-697.

DiDimiou 2014: S. Didioumi, "Local pottery production in the island of Cos, Greece from the early Byzantine Period. A preliminary report", $L R C W 4$, vol. I, 169-180.

VAn Doorninck 1989: F. H. van Doorninck Jr., “The Cargo Amphoras on the 7th century Yass1 Ada and 11th century Serçe Limanı Shipwrecks: Two Examples of a Reuse of Byzantine Amphoras as Transport Jars", BCH Supll, 13, 247-257.

VAN Doorninck 2015: F. H. van Doorninck Jr., "The seventh-century Byzantine Ship at Yassiada and her final voyage: present thoughts", (eds. D. N. Carlson, S. M. Kampbell, J. Leidwanger), Maritime studies in the wake of the Byzantine shipwreck at Yassiada, Turkey, Texas A\&M University Press, 205-216.

Dumankaya 2018: O. Dumankaya, "Bandırma İlçesi Şirinçavuş Mahallesi Antik Liman, Yerleşim ve Batık Potansiyelinin Tespiti Araştırmaları/ Survey for detection of potential Ancient Harbors, Settlements and Shipwrecks at the Şirinçavuş Quarter of Bandirma district", TINA, 10, 127-132.

Durliat ve Guillou 1984: J. Durliat, A. Guillou, "Le tarif d'Abydos, vers 492", $B C H, 108,581-598$.

ELton 2005: H. Elton, "The Economy of Southern Asia Minor and LR 1 amphorae", $L R C W$ 1, 691-695.

Fournet ve Pieri 2008: J - L. Fournet, D. Pieri, “Les 
dipinti amphoriques d'Antinoopolis. (eds. G. Bastianini, R. Pitaudi), Antinoupolis I, Istituto papirologico G. Vitelli, 175-216.

Garnsey ve Whittaker 1998: P. Garnsey, C. R. Whittaker, "Trade, industry and the urban economy", Cambridge Ancient History, vol. 13: The Late Empire, A.D. 337-425, Cambridge, 312-337.

Gerousi 2016: E. Gerousi, "The Commercial Relations Between Aegean and the Black Sea on the Basis of the Testimony of the Early Christian Amphoras", Proceedings of the Symposium on City Ports from the Aegean to the Black Sea. (eds.) F. Karagianni, U. Kocabaș, Medieval-Modern Networks 22nd-29th August 2015, İstanbul, 127-136.

Grant 2000: M. Grant, Roma'dan Bizans'a (Çev. Z. İlkgelen), İstanbul.

Gregory 2008: T. E. Gregory, Bizans Tarihi, (Çev. E. Ermert), İstanbul.

GÜNDÜz 2017: S. Gündüz, “Bursa'nın Antik Liman Kalıntıları”, Aktüel Arkeoloji, 57, 100-105.

Haldon 2007: J. F. Haldon, "Primary Sources", (eds. E. Jeffreys, J. F. Haldon, R. Cormack), The Oxford handbook of Byzantine studies, Oxford; New York, 21-30.

Hayes 1992: J. W. Hayes, Excavations at Saraçhane in Istanbul, vol. 2: Pottery, Princeton.

Hendy 1985: M. F. Hendy, Studies in the Byzantine monetary economy, c. 300-1450, Cambridge; New York.

Hopkins 1980: K. Hopkins, "Taxes and Trade in the Roman Empire (200 B.C. - A.D. 400).”, JRS, 70, 1980, 101-125.

IACOMi 2010: V. Iacomi, "Some Notes on Late-Antique Oil and Wine Production in Rough Cilicia (Isauria) on the Light of Epigraphic Sources: Funerary Inscriptions from Korykos, LR 1 Amphorae Production in Elaiussa Sebaste and the Abydos Tariff", (eds. Ü. Aydınoğlu, A. K. Şenol), Antik çă̆da Anadolu'da zeytinyağı ve şarap üretimi, 19-32.

Jones 1964: A. H. M. Jones, The later Roman empire, 284-602: A social economic and administrative survey, vol. 2, Oxford.

KAÇAR 2005: T. Kaçar, "Eskiçağ Akdeniz dünyasında siyasal birliğin sonu: Romalılar ve kuzey komşuları", Doğu Batı, 34, 203-222.

KAegi 1985: W. Kaegi, "The annona militaris in the

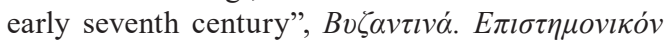

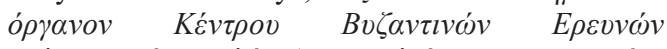

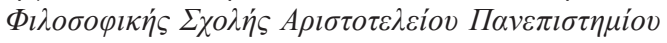
$\Theta \varepsilon \sigma \sigma \alpha \lambda$ ovík $\uparrow$, , 13, 591-596.

Kara 2015: Ü. Kara, "Yenikapı Limanı'nda Ele Geçen Damgalı Amphoralar", (eds. A. Diler, A. K. Şenol, Ü. Aydınoğlu), Antikçăg'da Doğu Akdeniz'de Zeytinyağl ve Şarap Üretimi, İstanbul, 243-250.

KARA 2016: Ü. Kara, "Küçükçekmece Göl Havzas1
Arkeolojik Kazılarında Yürütülen Amphora Çalışmaları", TINA, 6, 50-63.

Kara 2017: Ü. Kara, "Küçükçekmece Göl Havzası (Bathonea?) Kazıları'nda Ele Geçen Dipintolu LR 2 ve Damgalı LR 13 Amphoraları", (ed. Ş. Aydıngün), İstanbul Küçükçekmece Göl Havzası Kazıları / Excavations of Küçükçekmece Lake Basin (Bathonea), İstanbul, 277-285.

Kara 2019: Ü. Kara, GeçAntik Çăg’da (M.S. 4. - 7. yüzyıl) Doğu Akdeniz'de Üretilen Ticari Amphoralarda Dipinti, Graffiti ve Mühür Kullanımı, Ege Üniversitesi Sosyal Bilimler Enstitüsü Arkeoloji Anabilim Dalı, İzmir (Yayınlanmamış Doktora Tezi).

Karagiorgou 2001: O. Karagiorgou, "LR 2: A container for the military annona on the Danubian border?", (eds. S. Kingsley, M. Decker), Economy and exchange in the East Mediterranean during late antiquity, Proceedings of a conference at Somerville College, Oxford - 29th May, 1999, 129-166.

Kazdan 1991: (ed. A. Kazdan) The Oxford dictionary of Byzantium, New York; Oxford.

KingSLey 2001: S. Kingsley, "The Economic Impact of the Palestinian Wine Trade in Late Antiquity", (eds. S. Kingsley, M. Decker), Economy and Exchange in the East Mediterranean during Late Antiquity, Proceedings of a Conferance at Somerville College, Oxford, 29th May 1999, 44-68.

KingSLey 2013: S. Kingsley, "Late antique trade. Research methodologies and field practices", Theory and practice in late antique archaeology, 113-138.

KingSLey ve Decker 2001: S. Kingsley, M. Decker, "New Rome, New Theories on Inter-Regional Exchange. An Introduction to the East Mediterranean Economy in Late Antiquity", Economy and Exchange in the East Mediterranean during Late Antiquity, (eds.) S. Kingsley, M. Decker, Proceedings of a Conferance at Somerville College, Oxford, 29th May 1999, 1-27.

LAdStÄtter 2011: S. Ladstätter, "Bizans Döneminde Ephesos", (eds. F. Daim, S. Ladstätter), Bizans Döneminde Ephesos, İstanbul, 3-28.

LAIOU 2002: A. E. Laiou, "Economic and Non-Economic Exchange", (ed. A. E. Laiou), The economic history of Byzantium: From the seventh through the fifteenth century, Washington D. C., 665-680.

Lauffer 1971: G. A. V. 2 Diocletianus, (Çev. S. Lauffer), Diokletians Preisedikt, Berlin.

LEIDWANGER 2014: J. Leidwanger, "A preliminary archaeometric analysis of the Late Roman 1 amphoras from the cargo of the seventh-century Yassiada shipwreck, Turkey" $L R C W$ 4, vol. 2, 897-906.

LONG ve VOLPE 1998: L. Long, G. Volpe, "Le chargement de l'épave 1 de la Palud (VIe s.) à Port-Cros (Var). 
Note préliminaire", Fouilles à Marseille: Les mobiliers (1er-7e siècles ap. J.-C.), 317-342.

Mango 2008: C. A. Mango, Bizans Yeni Roma Imparatorluğu. (Çev. G. Ç. Güven), İstanbul.

Mango 2009: M. M. Mango, "Byzantine Trade: Local, Regional, Interregional and International". (ed. M. M. Mango), Byzantine Trade, 4th-12th Centuries. The Archaeology of Local Regional and International Exchange, Papers of the Thirty-eight Spring Symposium of Byzantine Studies. St. John's College University of Oxford, March 2004, 3-14.

MARIA 2011: P. Maria, "Diocletian's Edict on Maximum Prices of 301 AD. A fragment found in Aigeira", Historia.scribere 3, 360-398.

MacMullen 1980: R. MacMullen, "How big was the Roman army?", Klio, 62,2, 451-460.

Minchev 2011: A. Minchev, "Early Byzantine Amphorae with Graffiti and Christian Stamps from a Shipwreck in the Bay of Varna (Bulgaria)", (eds. C. Tzochev, T. Stoyanov, A. Bozkova), Patabs 2, Acts of the International round table held in Kiten, Nessebar and Sredetz September 26-30, 2007, 143-159.

Mitchell 2016: S. Mitchell, Geç Roma Imparatorluğu Tarihi M.S. 284-641, (Cev. T. Kaçar), Ankara.

Opait 1987: A. Opait, "Amfore romane de mare capacitate. Consideraţii tipologice", Studii şi cercetări de istorie veche şi arheologie, 38, $245-258$.

Opait 2004: A. Opait, Local and imported ceramics in the Roman province of Scythia (4th-6th centuries $A D)$ : Aspects of economic life in the province of Scythia. Oxford.

OPAIT, baskıda: A. Opait, $L R C W 6$ (Yayın aşamasında)

Opait ve Diamanti 2014: A. Opait, C. Diamanti, "Imperial stamps on Early Byzantine amphoras: The Athenian Agora examples", RCRF Acta, 43, 55-61.

ÖNiz 2016: H. Öniz, Doğu Akdeniz'de Amphoralar. İstanbul.

PAterson 2010: J. Paterson, Roma Dünyasında Ticaret ve Tüccarlar: Ölçek, Yap1 ve Örgütlenme”, Ticaret, Tüccarlar ve Antik Kent (Çev. Ö. Harmanşah), İstanbul, 136-151.

Papanikolaou 2014: P. Papanikolau, Impressions of Authority. Iconography and Prosopography of the Eparchs on Early Byzantine Stamped

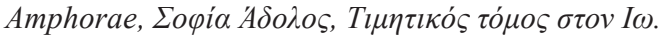
П $\alpha \pi \alpha \chi \rho \imath \sigma \tau o \delta o v ́ \lambda o v$, Rodos, 171-194. (Yunanca)

PeACOCK 1984: D. P. S. Peacock, "Amphorae: Typology and Chronology", (eds. M. G. Fulford, D. P. S. Peacock), The avenue du President Habib Bourguiba, Salammbo: 2. (1. The avenue $d u$ President Habib Bourguiba, Salammbo), Sheffield, 116-128.

Peacock ve Williams 1986: D. P. S. Peacock, D. F.
Williams, Amphorae and the Roman economy: An introductory guide. London: Longman.

PIERI 2005: D. Pieri, Le commerce du vin oriental à l'époque byzantine (Ve-VIIe siècles): Le témoignage des amphores en Gaule, Beyrouth.

Pieri 2007: D. Pieri, "Béryte dans le grand commerce méditerranéen (Ve-VIIe s. apr. J.-C.)", (ed. M. Sartre), Productions et échanges dans la Syrie gréco-romaine. Actes du 2e colloque international sur la Syrie antique (Tours, 12-13 juin 2003), suppl. Topoi, 8, 297-327.

PIERI 2012: D. Pieri, "Regional and Interregional Exchanges in the Eastern Mediterrnean during the Early Byzantine Period", (ed. C. Morrison), Trade and markets in Byzantium, Washington, 28-49.

Pollard 2006: N. Pollard, "The Roman Army", (ed. D. S. 1. Potter), A companion to the Roman Empire, Malden, Mass, 206-227.

REYNOLDS 2018: P. Reynolds, "The Supply Networks of the Roman East and West: Interaction, Fragmentation, and the Origins of the Byzantine Economy", Trade, commerce, and the state in the Roman world, 353-395.

Riley 1979: J. A. Riley, "The coarse pottery from Berenice", Excavations at Sidi Khrebish, Benghazi (Berenice), 2, 91-467.

RILEY 1981: J. A. Riley, "The pottery from the cisterns 1977. 1, 1977. 2, 1977. 3.”, Excavations at Carthage conducted by the University of Michigan, 6, 85-124.

Robinson 1959: H. S. Robinson, Pottery of the Roman period: Chronology. Princeton, 1959.

Rотн 1994: J. Roth, "The size and organization of the Roman imperial legion", Historia (Stuttgart), 43, $1-4,346-362$.

SARnOwski 2015: T. Sarnowski, "Danubian Provinces", (eds. Y. Le Bohec, G. Brizzi), The encyclopedia of the Roman Army, West Sussex, 279-290.

SCORPAN 1977: C. Scorpan, "Contribution à la connaissance de certains types céramiques romanobyzantins (4e $-7 \mathrm{e}$ siècles) dans l'espace istropontique", Dacia, 21, 269-298.

Swan 2007: V. G. Swan, "Dichin (Bulgaria): Interpreting the ceramic evidence in its wider context", The transition to Late Antiquity on the Danube and beyond, 251-280.

Swan 2010: V. G. Swan, "Dichin (Bulgaria): the destruction deposits and the dating of Black Sea amphorae in the fifth and sixth Centuries A.D.", Patabs 1, Actes de la Table Ronde internationale de Batoumi et Trabzon, 27-29 avril 2006. Istanbul, 107-118.

Sztetyllo ve Borkowski 1986: Z. Sztetyllo, Z. Borkowski, "Un timbre céramique byzantin de l'éparque de Constantinople", BCH Supll, 13, 649-653.

Şenol 2003: A. K. Şenol, Marmaris Müzesi Ticari 
Amphoralarl, Ankara, 2003.

ŞENOL 2005: A. K. Şenol, "Antik Dönem Ekonomisinin Kurgusunda Seramik Buluntuların Yeri, Sorunlar", $O L B A, 12,125-138$.

ŞENol 2009: A. K. Şenol, AETAM (Arslan Eyce Taşucu Amphora Müzesi)'da Bulunan Ticari Amphoralar ve Akdeniz'de Ticaretin İzleri, Mersin.

ŞENOL 2018: A. K. Şenol, Commercial amphoras in the Graeco-Roman Museum of Alexandria, Alexandrie.

Treadgold 2015: W. T. Treadgold, "Economy and the Army: Late Empire”, (eds. Le Y. Bohec, G. Brizzi), The encyclopedia of the Roman Army, West Sussex, 362-366.

TÜRE 2009: F. Türe, "Roma İmparatorluğu'nda Annona Kurumu”, Doğu-Batı, 50, 115-126.

WARD - Perkins 2001: B. Ward-Perkins, "Specialisation, Trade, and Prosperity: an Overview of the Economy of the Late Antique Eastern Mediterranean", (eds. S. Kingsley, M. Decker), Economy and exchange in the East Mediterranean during late antiquity, Proceedings of a conference at Somerville College, Oxford - 29th May, 1999, 167-178.

Williams ve Friell 1999: S. Williams, G. Friell, "Imperial Wealth and Expenditure", The Rome that did not fall: The survival of the East in the fifth century. London, 115-135.

Whittaker ve Garnsey 1998: C. R. Whittaker, P. Garnsey, "Rural life in the later Roman empire", Cambridge Ancient History, vol. 13, 277-311.

Zeest 1960: I. B. Zeest, Keramicheskaya Tara Bospora. Issledorani po arkheologia, SSSR. (Rusça)

ZeMer 1978: A. Zemer, Storage jars in ancient sea trade, Haifa.
Makale Gönderim Tarihi: 14.12.2020

Makale Kabul Tarihi: 23.06.2021

\section{ÜLKÜ KARA}

Orcid ID: 0000-0002-4276-7205

Manisa Celal Bayar Üniversitesi Fen-Edebiyat Fakültesi, Arkeoloji Bölümü, Manisa/TÜRKIYY

ulquba@gmail.com 

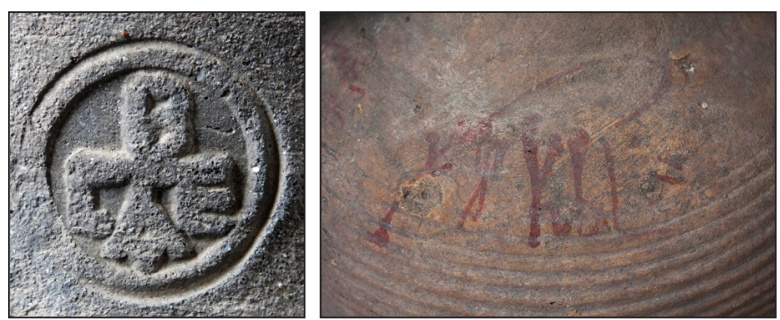

Fig. 1. a) Kara 2019: Kat. No. 1 (Kara 2015: Fig. 5); b) Kara 2019:Kat. No. 26a (Çibuk2019: Kat. No:27; Fotoğraf:S. Kara)
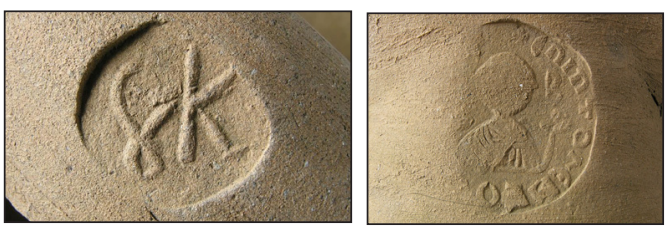

Fig. 2. a-b) Kara 2019: Kat. No: 49a-b (Kara 2015: Fig. 3a-b)
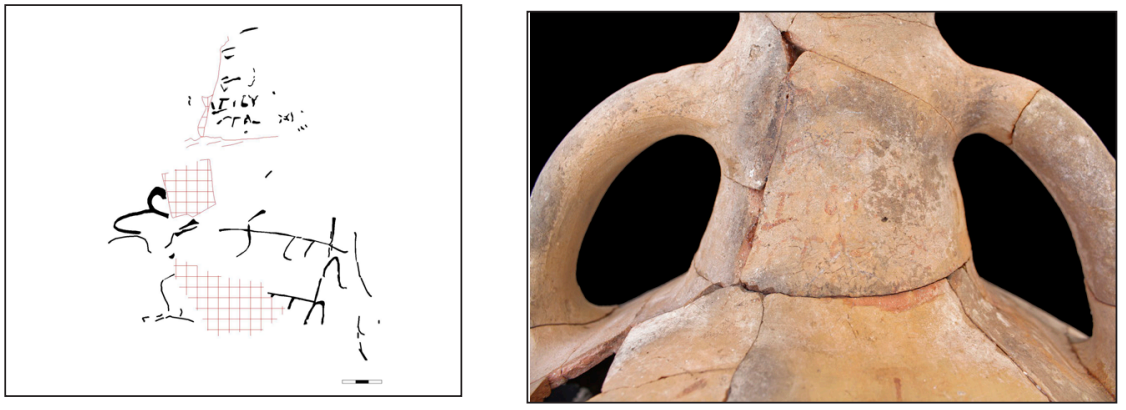

Fig. 3a-b. Kara 2019: Kat. No. 140a (Kara 2016: Fig. 10a-c; Kara 2017: 278-80, Res. 3a-d, Çiz. 2a-b)

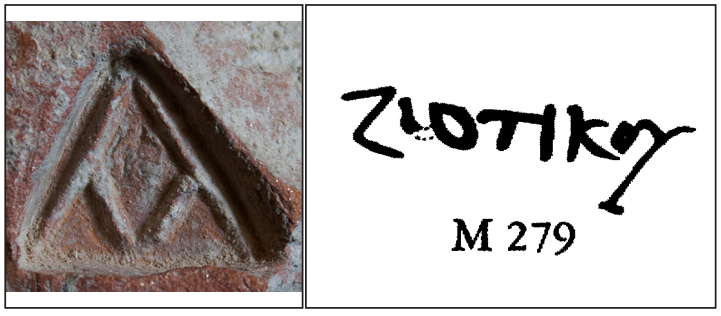

Fig. 5. a) Kara 2019: Kat. No. 178 (Cankardeş - Şenol 2015: 238, Res. 13; Fotoğraf: S. Kara); b) Kara 2019: Kat. No. 190 (Robinson 1959: 110, PI. 58, M 279)
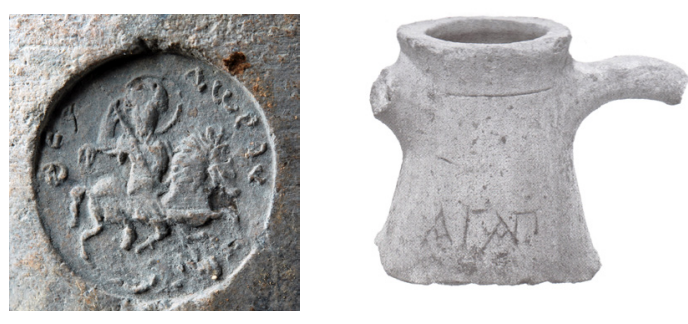

Fig. 6. a) Kara 2019: Kat. No. 219 (Kara 2015: Fig. 9ab); b) Kara 2019: Kat. No. 236 (Minchev 2011: Fig. 12)
Fig.4.Kara 2019: Kat. No. 175c (Fotoğraf / Çizim: Ü. Kara)

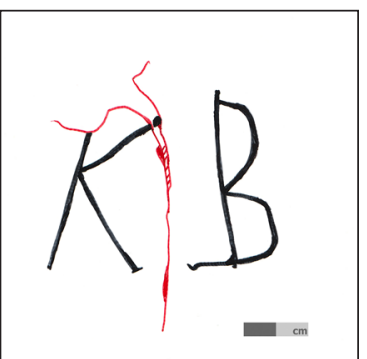

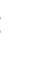

